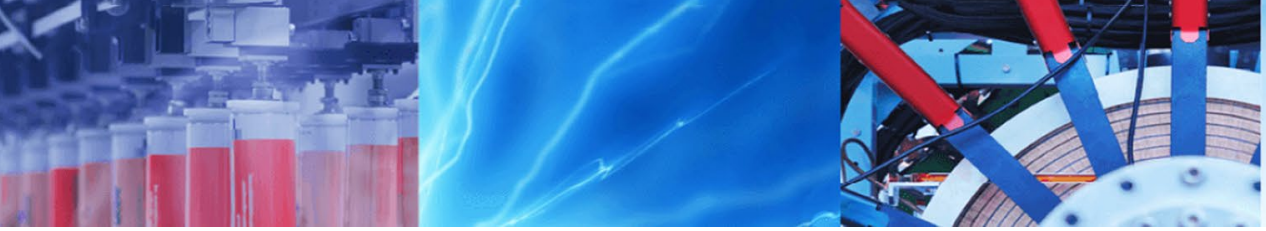

Research Article

\title{
Techno-spatial assessment of waste cooking oil for biodiesel production in Pakistan
}



Received: 25 September 2019 / Accepted: 7 April 2020 / Published online: 15 April 2020

(c) Springer Nature Switzerland AG 2020

\begin{abstract}
This study presents a take on employing the principles of waste valorization to solve the long-standing problem of finding sustainable resources for biodiesel production. The biodiesel production has always met with a competition with food security and land use. This has limited the scope of the technology to laboratory experiments only. This study aims to assess the geospatial availability of waste cooking oil in Pakistan to map its biodiesel production potential. Owing to the resource posing no land use or food security challenges, a resource assessment using geographical information systems was carried out. The waste cooking oil availability was estimated using the statistics on per capita edible oil consumption with a realistic consumption and collection factor applied to it. The available residual cooking oil was subjected to the transesterification with a rather conservative conversion to the biodiesel at $66.25 \%$ to keep the estimates realistic. The study results in heat maps of all the different regions and provinces of the country. The findings suggest that Punjab province is the highest potential province with 249,260 tonnes of biodiesel production annually. Karachi district is the highest potential district with a potential of 36,156 tonnes of biodiesel production in a year. The study paves ways for investment sector in the study area to identify highest potential regions to invest in. It also motivates the scientific community to step outside of experimental research on waste cooking oil's biodiesel production potential and perform resource assessments and techno-economic analyses on the technology for its widespread adoption.

Graphic abstract PS-The callouts do not represent any geographical locations instead they represent the shade of the gradient they correspond to in terms of red being the gradient shade for the problems and the green being the gradient shade for the remedial contributions made by the study. The use of the map of the study area is because of the contextual important of the map in a resource and potential assessment that is geospatial in nature.
\end{abstract}

$\triangle$ Muhammad Ali Qamar, aliofficial002@gmail.com| 1 U.S. - Pakistan Center for Advanced Studies in Energy, National University of Sciences and Technology, Islamabad, Pakistan. ${ }^{2}$ Faculty of Agricultural Engineering and Technology, University of Agriculture, Faisalabad, Pakistan. 


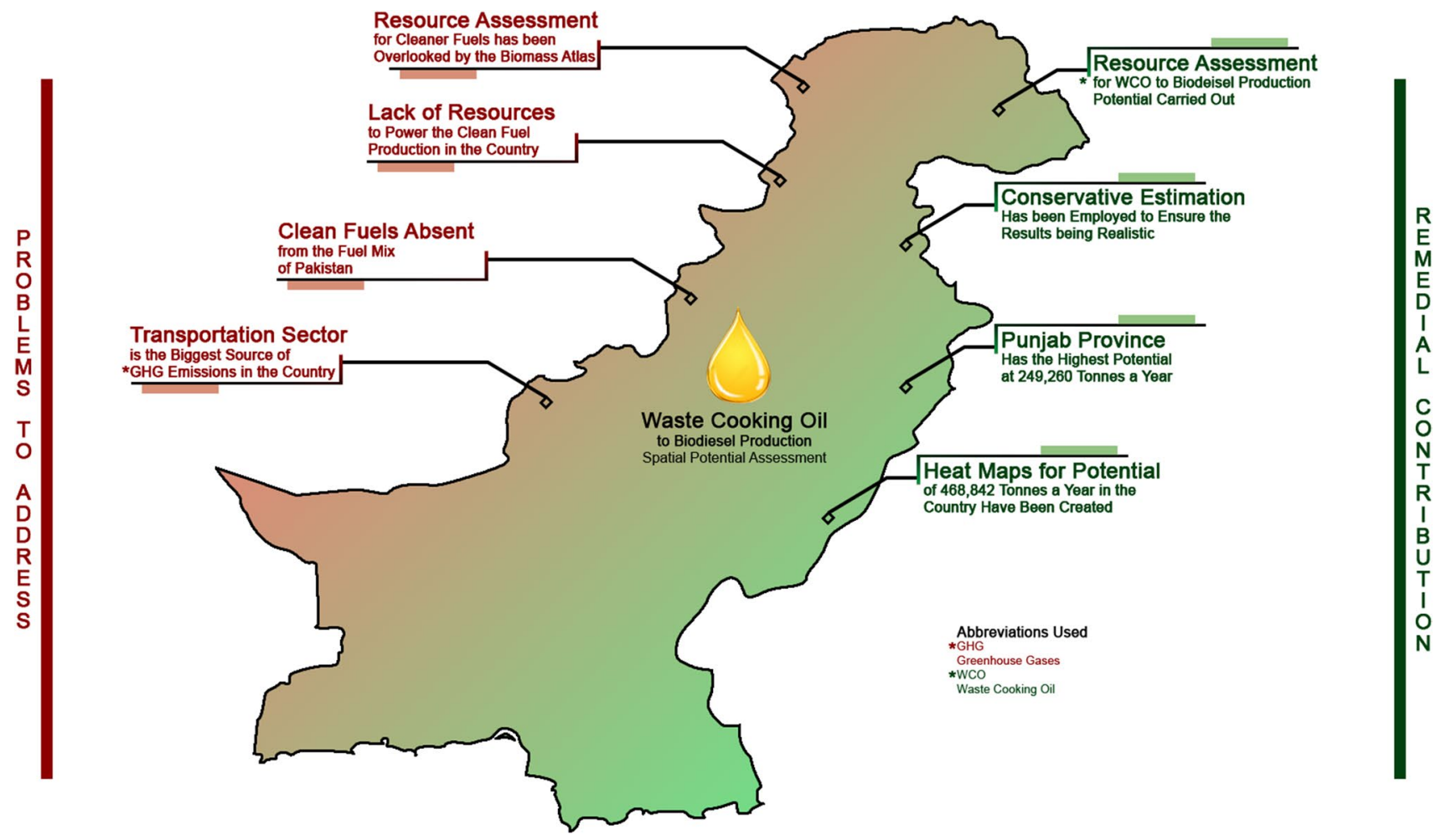

Keywords Waste cooking oil to biodiesel - Biodiesel production - Waste to energy - Clean energy - Bioenergy - Waste cooking oil - Spatial potential assessment . Biodiesel production in Pakistan

\section{Abbreviations}

$\begin{array}{ll}\text { FOI } & \text { Fraction of investment } \\ \text { LC } & \text { Labor cost } \\ \text { UC } & \text { Utilities' cost } \\ \text { WTC } & \text { Waste treatment cost } \\ \text { RMC } & \text { Raw materials cost } \\ \text { AEDB } & \text { Alternate Energy Development Board } \\ \text { FAME } & \text { Fatty acids methyl ester } \\ \text { WCO } & \text { Waste cooking oil } \\ \text { GIS } & \text { Geographical information systems } \\ \text { AJK } & \text { Azad Jammu \& Kashmir } \\ \text { GB } & \text { Gilgit Baltistan } \\ \text { FATA } & \text { Federally Administered Tribal Areas }\end{array}$

\section{Introduction}

The global boom of biodiesel replacement with the fossil fuels has taken off pretty well in the last decade due to a projected run-out of the fossil fuel reserves in the world. An attractive benefit offered by the biofuels is the ecofriendliness of these fuels over the conventional fossil fuels due to them being carbon neutral, alongside their sustainability aspect. Both the issues that the biofuels cater to, have their own scale and gravity in Pakistan. With the sixth largest population in the world [1], Pakistan is a developing country with an import-heavy economy which happens to be at the highest potential risk from the effects of climate change in the form of droughts and floods [2, 3]. One of the largest contributors towards the imports in the country is the crude oil that powers the country's transport, power and electricity sectors with the local oil reserves contributing a meager bit to the country's very high fuel demand [4]. The transport sector in the country, with a usage of over 14.6 million tonnes of imported crude oil based fuels [5], is the sector that contributes the most towards the emission of greenhouse gases in the country which eventually escalate the causes of the climate change [3]. An appropriate fix for both of the issues pertaining to the sustainability of the fuel supplies with an environmentally benign alternative is the production of biodiesel in the country.

Alternate Energy Development Board (AEDB) is a dedicated institution in the country to introduce and regulate the alternate energy technologies that include, solar, wind, micro-hydel and bio energy technologies [6]. The country's first renewable energy policy was constituted back in 2006 by the AEDB which outright overlooked the bio-energy options and rather focused more on solar and wind energy 
technologies [7] the effects of which, are playing out in the form of well-established markets and a developed infrastructure for both solar and wind energy in the country and a rather lack luster focus on bio-energy adoption $[8,9]$. There have been some efforts made by the AEDB in tapping the untapped potential of bio-energy in the country, but the most of it is in the form of agro-industrial waste to energy to be taken up by the sugar and rice mills in the country [6]. AEDB also worked with World Bank to compile the country's first ever biomass atlas which was a promising effort towards the bio-energy adoption but the inclusion of the potential resources for biodiesel production was absolutely overlooked in the atlas [10]. Some of the efforts made by AEDB towards biodiesel production from Jatropha and promotion of its plantation in the Sindh province have been reported and endorsed by various authors [11-13], which indicates the institution's positive approach towards the exploitation of indigenous resources for biodiesel production is in place.

In terms of the raw resource availability for the biodiesel production in the country, the first generation resources i.e. the energy crops are certainly not an option because the country, despite having a large part of its population associated with agriculture and one of the world's largest irrigation networks is unable to supply for its needs even for the edible oil $[14,15]$. The country's economy has had a burden of a huge import bill of 3.2 million tonnes of edible oils costing over 3 billion USD to the country's already struggling economy in the year 2017-18 [15]. The country's local edible oil production only accounts for fulfilling the $12 \%$ of the country's requirement with a production of 0.431 million tonnes recorded in the year 2017-18 which rules out the possibility of avoiding this heavy toll on the country's economy [15]. Another possible untouched contender for the raw resource for biodiesel production is the microalgae. The suitability of the marginal lands as well as the immense saline lands in the country for the algal culture has been reported by various authors $[13,16,17]$ but the pool of this resource doesn't exist and thus needs introduction for cultivation and biodiesel production which, considering the overall slow pace of the AEDB in bringing the renewable energy technologies about [18], is a far-fetched approach. Demand for a readily available resource for achieving the target set by the Government of Pakistan to reach $10 \%$ biodiesel blending into the country's overall fuel usage by the year 2025 is clearly established $[13,19,20]$. This brings us to a rather new yet promising contender for the resource supply for biodiesel production in the country to meet the target, waste cooking oil (WCO). The scientific community has been very busy investigating the ways to improve the fatty acid methyl ester (FAME) yield from the transesterification of the waste cooking oil by employing different approaches, conditions and catalysts. The amount of work that has been done on the waste cooking oil to biodiesel production is promising enough to take it up as a resource for biodiesel production here in Pakistan considering a very high use of the cooking oil in the country [21,22]. This study engages the well-established GIS based resource potential to assess the biodiesel potential from WCO in Pakistan $[23,24]$. The technique of spatial assessment of a resource availability across a study area is one of the most comprehensive and thorough approaches towards the potential identification posed by different resources and it has thus been widely used among the scientific community to study the potential posed by different resources in different study areas $[25,26]$.

A similar study employed simulation based on a GIS system to project the potential capacity of the biodiesel plants based on the biomass availability in Greece. The study employed S-curve forecasting model for projecting the temporal changes in the capacity as well as the number of units pertaining to the biodiesel plants in the study area [27]. Another study carried out for the Europe employed a similar approach to optimize the location of the biodiesel production plants based on brassica plants as a resource in Sicily, Italy. The study carried out point weight suitability analysis employing a GIS and Matlab based centroid mathematical model to suggest the optimized biodiesel point location in the study area [28]. Another study assessed the policy aspects of the biodiesel production in Thailand, which aims to achieve $25 \%$ of the biofuel share in the country's mix by 2021. The study employed GIS based mapping to highlight the potential for a sustainable supply of the resource to produce biodiesel [29]. Another study to employ the GIS based mapping for biodiesel production supply in Iran was carried out which considered the second generation resource microalgae to be the feedstock for the aimed production. The study carried out the site suitability assessment based on the resource availability for the study area based on the GIS program to optimize the power plant location [30]. Various other studies have been carried out employing similar GIS based models to carry out the resource assessment for numerous resources such as biomass to bio-energy, solar energy and wind energy to name a few [31-33].

The use of waste cooking oil in the production of biodiesel through transesterification is not only preferable because of the process-ready availability of the resource but also due to the less energy intensiveness of the overall process compared to the extraction of biodiesel from all of the first, second and third generation biodiesel production resources as it is directly put to transesterification without the energy intensive steps of the oil extraction, or seed pressing etc. $[34,35]$. The recent wave around the technology among the scientific community is rather new 
compared to the other resources for biodiesel production like Jatropha or the microalgae. Nature of the resource calls upon an inter-disciplinary pool of scientists to carry out the process optimization therefore some very comprehensive approaches and studies to optimize biodiesel production have recently been carried out [36, 37]. Use of different catalysts has been studied to improve the process to an extent that the FAME yields of over $90 \%$ have also been reported using different catalysts and conditions [38-40] The use of homogenous, heterogeneous, nanocatalysts has been studied but overall the performance of the process when catalyzed by alkali, alkoxides, hydroxides and alkaline metal oxides has been reported to be the most effective and if we compare the acid-base catalysts, the acid based catalysts have been found to be performing better under the higher alcohol to oil molar ratio exposure at moderate pressure and temperature [41, 42]. Various studies have also been performed analyzing the properties of the produced biodiesel as a fuel in conventional internal combustion engines and the fuel has been reported to be very competitive in the fossil fuel dominated liquid fuel arena, used both in the form of blends and independently [43-46]. Studies to evaluate the economics around the waste cooking oil to biodiesel have also been carried out, most of which have concluded in finding the cost of biodiesel to be less than the petro diesel with the payback period for the biodiesel production reported to be around 4 years which can vary depending upon the country and the conditions put on in the model [47, 48]. Equation 1 gives a general expression for the production cost evaluation of biodiesel from waste cooking oil per liter in a production plant [49].

Cost of production $0.304 \mathrm{FOI}+2.73 \mathrm{LC}+1.23(\mathrm{UC}+\mathrm{WTC}+\mathrm{RMC})$

where $\mathrm{FOI}$ is the fraction of the investment and the $\mathrm{LC}$, UC, WTC and RMC are the different costs namely the labor cost, cost of the utilities, waste treatment costs and the raw material costs respectively. These and various other scientific studies are more than convincing enough for the investors and the waste management companies to take up the waste cooking oil to biodiesel production as a trusted and implementable technology. In order for the idea to further strengthen, an availability assessment for the resource is rather necessary because the technical aspects are only reminiscent with the scientific community but in order for an idea to resonate with the policy makers, such evidences on the abundant resource availability are to be presented to them in a comprehensive manner.

Biodiesel research in Pakistan has mainly focused on the identification of the potential for production from nonedible oils or from the microalgae. Studies reviewing the available options to mainstream the biodiesel production from microalgae in the country [13], discussing the potential of the non-edible oilseed crops to be used for powering the biodiesel production [50] and the policy review of the biodiesel production in the country have been carried out in the recent past [11]. For the waste cooking oil to biodiesel production, a review article on the status quo of the technology in Pakistan was carried out. The study assessed the economics of a supply chain for a plant for producing biodiesel using waste cooking oil including the resource availability, the cost of acquiring and the possible emissions from the biodiesel to name a few. The study found the cost of production of the biodiesel from waste cooking oil in Pakistan based on the simulated models to be reasonably lower than the cost of petro-diesel in the country [12]. Another study carried out in Pakistan optimized the transesterification process to achieve $94 \%$ conversion of the waste cooking oil into the free fatty acids with an alkali based catalyst. The results of the study show a considerably higher production of biodiesel or FAME with the catalyst than without [38]. Another review of the biodiesel production from waste cooking oil deemed it to be a very suitable technology to increase on the biodiesel production in Pakistan was carried out. The study reviewed the prospects and opportunities the resource poses for biodiesel production in the country alongside establishing the reliability of the technology [38]. There has been some work done on the biodiesel production from waste cooking oil in the country, however, none of the studies have addressed a thorough and detailed resource availability assessment for the waste cooking oil to biodiesel production and that's the knowledge gap that this study is aimed at filling in on.

\section{Experimental methodology}

The availability of the waste cooking oil has been assessed by the per capita consumption of the cooking oil in the country and since the annual oil consumption of the country was reported in the Economic Survey of Pakistan to be 3.63 million tonnes in the year 2017-18 [15] and the population census carried out in the country gave the population of the country to be 207.77 million [15], combining this with the population data from Azad Jammu and Kashmir (AJK) and Gilgit Baltistan (GB) [34, 35], the total combined population is calculated to be $212.73 \mathrm{mil}-$ lion people thus yielding the per capita oil consumption to be 0.017 tonnes per person annually. The collectability factor for the waste cooking oil has been assumed to be $20 \%$ considering some of the social barriers as discussed by some of the authors for different countries in collecting the waste cooking oil from the masses $[51,52]$ and the lack of an existing network for such collection in Pakistan. 
The biodiesel extraction potential from the cooking oil was taken to be a rather conservative $66.25 \%$ than the optimistic $90 \%$ and above as reported by some authors [38-40] reported as an average from different types of waste cooking oils by a study [53] to keep the estimates realistic. The same metric was applied to each of the district's population to see the high potential districts across the provinces and across the country.

The Geographical Information Systems (GIS) were employed to create the spatial potential maps for the statistically assessed resource potential. The calculated per capita edible oil consumption as discussed earlier in this section after being subjected to both a collection factor and a conversion factor to the biodiesel was entered into a GIS program called ArcGIS version 10.1. It is to clarify that unlike some other studies that have performed resource assessment on bioenergy potential from crop residues using the remote sensing, this study relied on potential assessment outside of the GIS programs and without the remote sensing [54]. The reason for using such an approach is that the remote sensing cannot be employed to this instance as the potential being assessed is for the amount of waste cooking oil generated. The crop residue intensity can be mapped using remote sensing because it is detectable using land cover analysis. The waste production by the

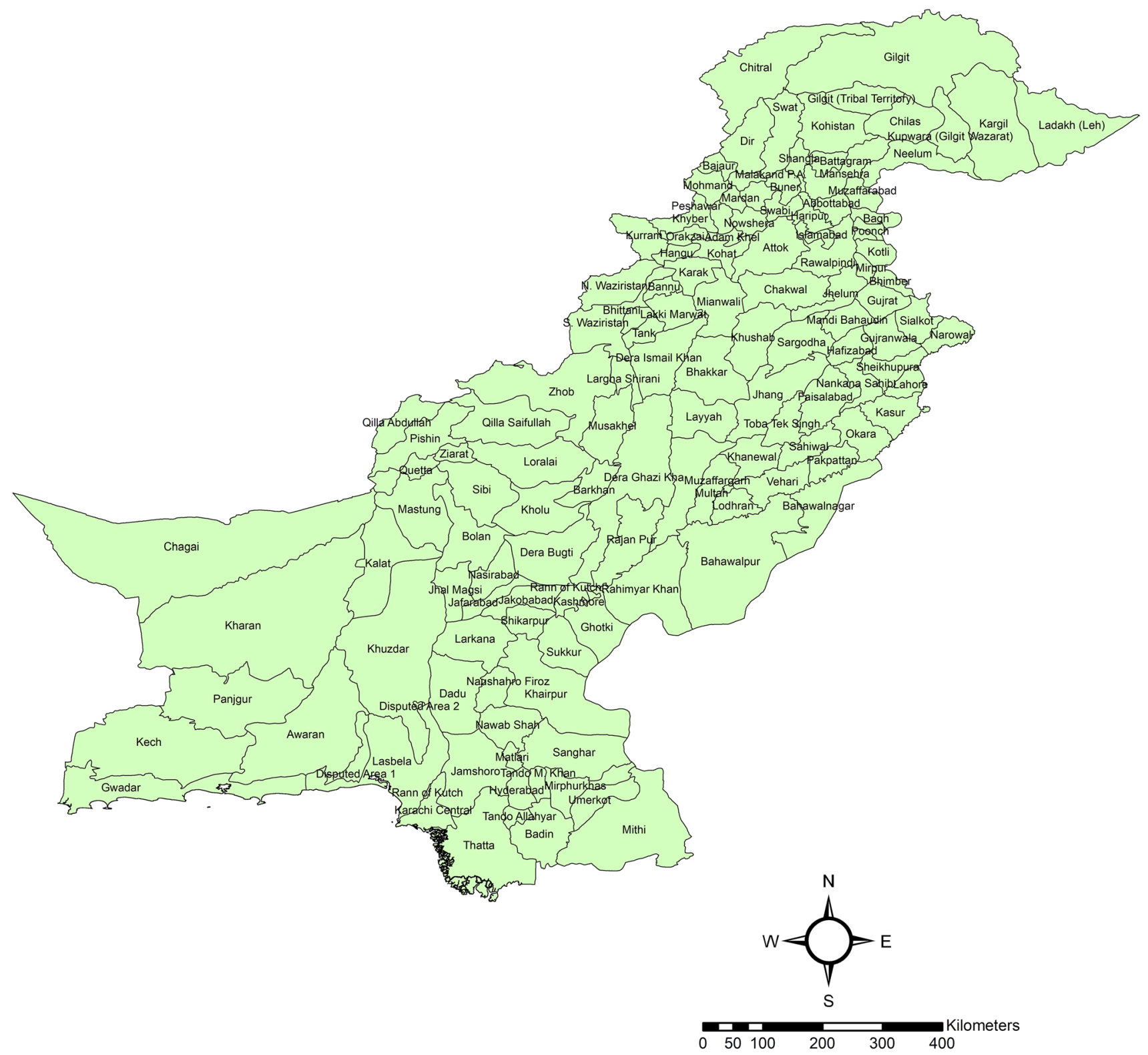

Fig. 1 Reference map of Pakistan with district names 
people for municipal solid waste or waste cooking oil in this instance cannot be remotely sensed using satellite imagery. Therefore ArcGIS 10.1 was employed only to create spatial heat-maps for the biodiesel production potential across the study area. The program was then used to create heat maps of the different regions of Pakistan clipped from the input raw maps using the tools within the program. The raw input maps with the geographical information of the country's territorial makeup were acquired from diva GIS which is a free online resource for such maps for about all of the countries across the globe. The heat maps were created province and region-wise for each of the 7 different administrative units in the country namely Punjab, Sindh, Balochistan, Khyber Pakhtunkhwa (KPK), AJK, Federally Administered Tribal Areas (FATA) and GB. A reference map with district names for understanding the heat maps is given in Fig. 1.
Table 1 Biodiesel production potential from waste cooking oil in Punjab

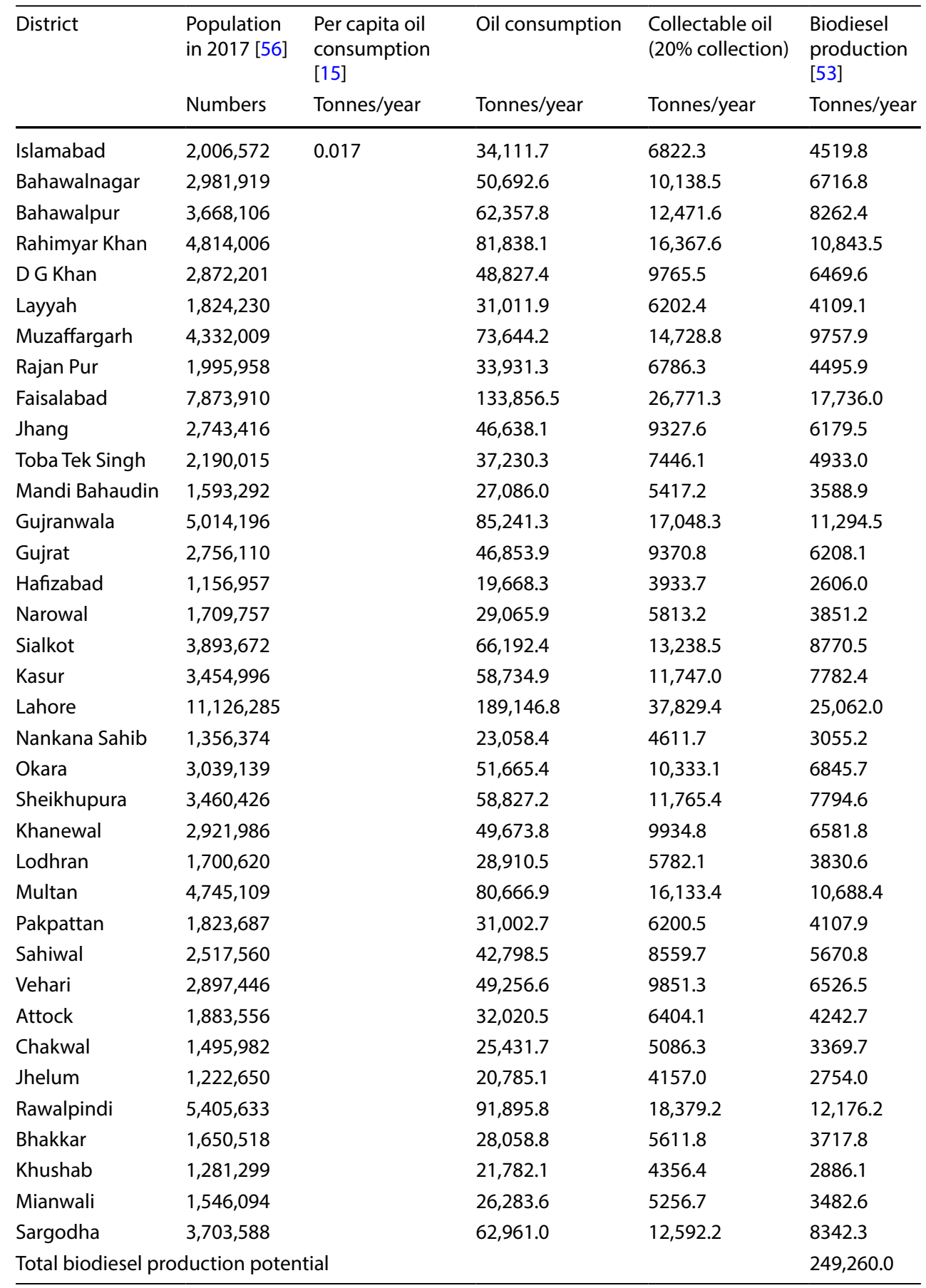


Fig. 2 Biodiesel from waste cooking oil potential across Punjab

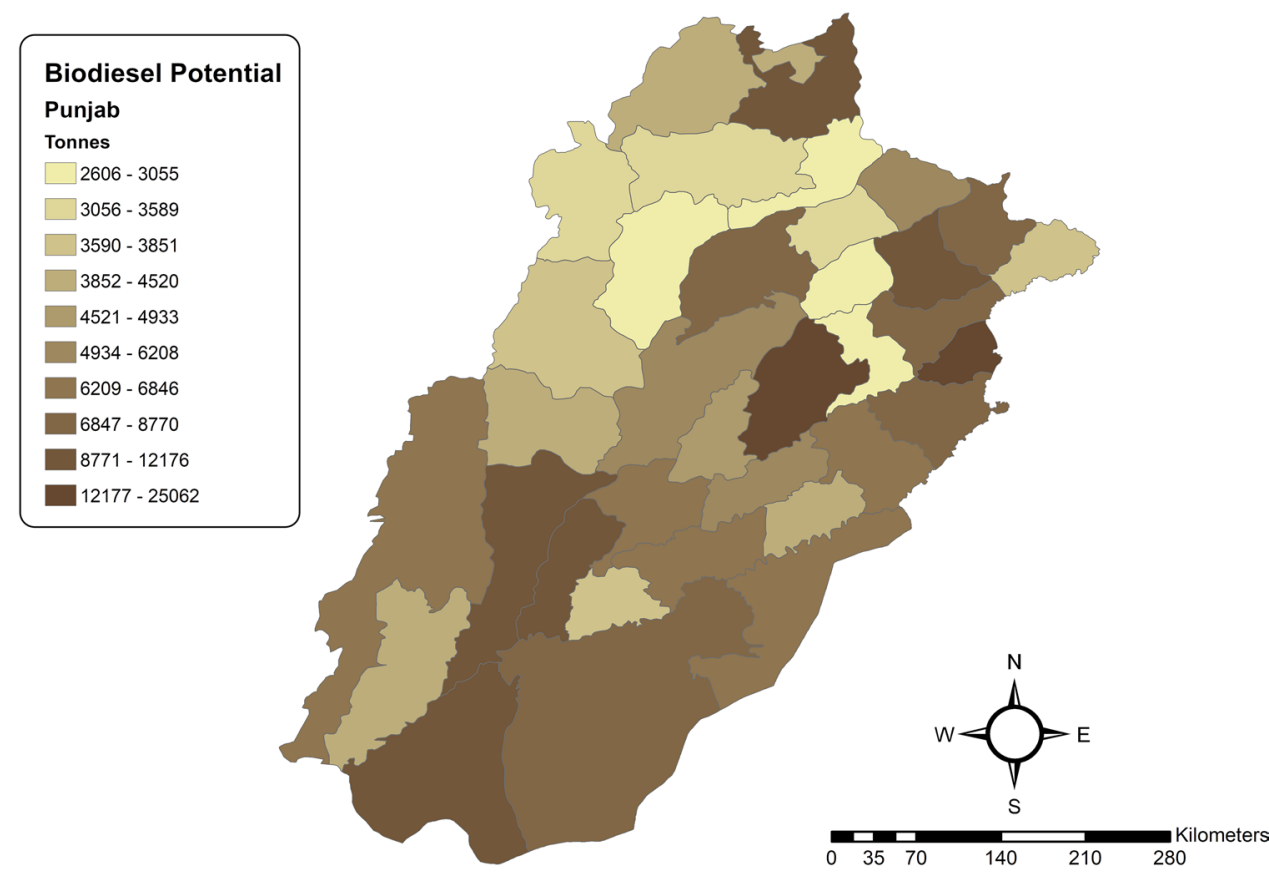

\section{Results and discussion}

The GIS based potential for the biodiesel production across each of the administrative units are given here in their respective sections.

\subsection{Punjab}

Punjab is the largest population province in the country [55] which translates into an overall higher potential from waste cooking oil to biodiesel production. The total potential offered by the province accounts for over half the potential of biodiesel production from waste cooking oil sitting at 249,260 tonnes of biodiesel as per the very conservative estimates which is still pretty high. The highest potential is offered by Lahore, Faisalabad and Rawalpindi
Fig. 3 Biodiesel from waste cooking oil potential across Sindh

\begin{tabular}{|c|}
\hline $\begin{array}{l}\text { Biodiesel Potential } \\
\text { Sindh }\end{array}$ \\
\hline Tonnes \\
\hline 1525 \\
\hline \begin{tabular}{|l|l|} 
& $1526-1885$ \\
\end{tabular} \\
\hline $1886-2453$ \\
\hline$\square 2454-2774$ \\
\hline 2775 - 3392 \\
\hline $3393-3492$ \\
\hline $3493-4065$ \\
\hline $4066-4954$ \\
\hline $4955-5416$ \\
\hline $5417-36156$ \\
\hline
\end{tabular}
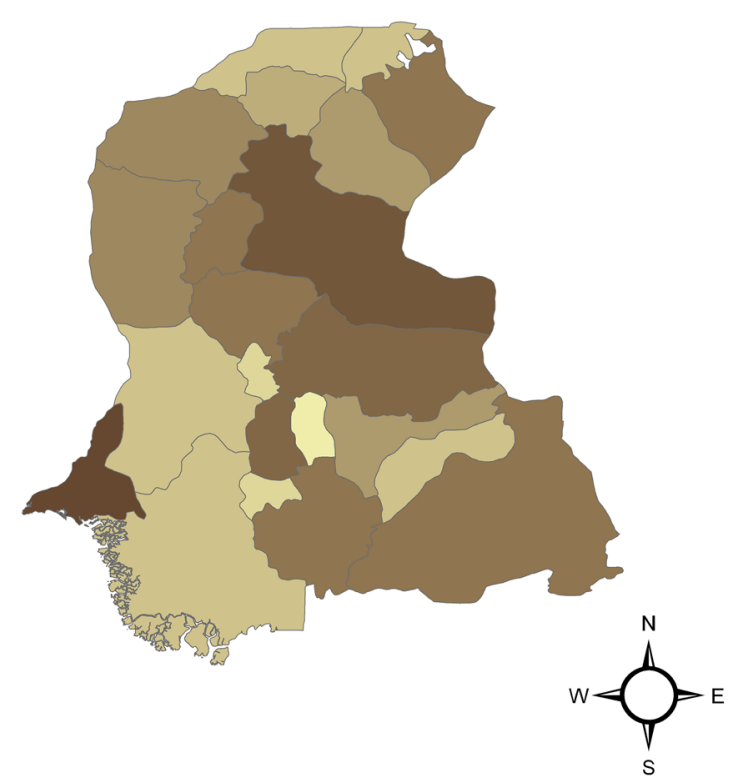

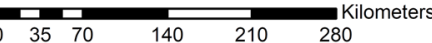

SN Applied Sciences

A SPRINGER NatURE journa 
Table 2 Biodiesel production potential from waste cooking oil in Sindh

\begin{tabular}{|c|c|c|c|c|c|}
\hline \multirow[t]{2}{*}{ District } & $\begin{array}{l}\text { Population in } \\
2017 \text { [56] }\end{array}$ & \multirow{2}{*}{$\begin{array}{l}\text { Per capita oil con- } \\
\text { sumption [15] } \\
\text { Tonnes/year }\end{array}$} & \multirow{2}{*}{$\begin{array}{l}\text { Oil consumption } \\
\text { Tonnes/year }\end{array}$} & \multirow{2}{*}{$\begin{array}{l}\text { Collectable oil }(20 \% \\
\text { collection) } \\
\text { Tonnes/year }\end{array}$} & \multirow{2}{*}{$\begin{array}{l}\text { Biodiesel production [53] } \\
\text { Tonnes/year }\end{array}$} \\
\hline & Numbers & & & & \\
\hline Badin & $1,804,516$ & \multirow[t]{23}{*}{0.017} & $30,676.8$ & 6135.4 & 4064.7 \\
\hline Dadu & $1,550,266$ & & $26,354.5$ & 5270.9 & 3492.0 \\
\hline Hyderabad & $2,199,463$ & & $37,390.9$ & 7478.2 & 4954.3 \\
\hline Jamshoro & 993,142 & & $16,883.4$ & 3376.7 & 2237.1 \\
\hline Matiari & 769,349 & & $13,078.9$ & 2615.8 & 1733.0 \\
\hline Tando Allahyar & 836,887 & & $14,227.1$ & 2845.4 & 1885.1 \\
\hline Tando M Khan & 677,228 & & $11,512.9$ & 2302.6 & 1525.5 \\
\hline Thatta & 979,817 & & $16,656.9$ & 3331.4 & 2207.0 \\
\hline Karachi & $16,051,521$ & & $272,875.9$ & $54,575.2$ & $36,156.1$ \\
\hline Jacobabad & $1,006,297$ & & $17,107.0$ & 3421.4 & 2266.7 \\
\hline Kashmore & $1,089,169$ & & $18,515.9$ & 3703.2 & 2453.4 \\
\hline Larkana & $1,524,391$ & & $25,914.6$ & 5182.9 & 3433.7 \\
\hline Shikarpur & $1,231,481$ & & $20,935.2$ & 4187.0 & 2773.9 \\
\hline Mirpurkhas & $1,505,876$ & & $25,599.9$ & 5120.0 & 3392.0 \\
\hline Mithi & $1,649,661$ & & $28,044.2$ & 5608.8 & 3715.9 \\
\hline Sanghar & $2,057,057$ & & $34,970.0$ & 6994.0 & 4633.5 \\
\hline Umerkot & $1,073,146$ & & $18,243.5$ & 3648.7 & 2417.3 \\
\hline Ghotki & $1,646,318$ & & $27,987.4$ & 5597.5 & 3708.3 \\
\hline Khairpur & $2,404,334$ & & $40,873.7$ & 8174.7 & 5415.8 \\
\hline Naushahro Firoz & $1,612,373$ & & $27,410.3$ & 5482.1 & 3631.9 \\
\hline Nawab Shah & $1,612,847$ & & $27,418.4$ & 5483.7 & 3632.9 \\
\hline Sukkur & $1,487,903$ & & $25,294.4$ & 5058.9 & 3351.5 \\
\hline \multicolumn{4}{|c|}{ Total biodiesel production potential } & & $103,081.2521$ \\
\hline
\end{tabular}

districts due to their high populations with the highest potential offered by Lahore of 25,062 tonnes per year of biodiesel production potential from the waste cooking oil followed by Faisalabad at 17,736 tonnes per year. It is to note that this high amount of biodiesel produced from the waste cooking oil in these districts can easily be used by local transport sectors in these districts. The detailed calculation and district-wise potential across Punjab is given in Table 1. The heat map for the potential across Punjab is given in Fig. 2.

\subsection{Sindh}

Sindh is the second highest population district in the country, the most of which, comes from Karachi, the trade and commerce hub of Pakistan. The unmatched peak of Karachi in the southwest of the province can be seen in the Fig. 3 which sits at 36,156 tonnes per year of biodiesel production potential followed by Sanghar and Hyderabad with a massive margin, which both sit at 5416 tonnes per year and 4954 tonnes per year of biodiesel production from waste cooking oil. The total potential for the biodiesel production as per the conservative estimates is 103,081 tonnes which is less than half the potential offered by Punjab. The detailed calculation and district-wise potential is given in Table 2.

\subsection{Khyber Pakhtunkhwa (KPK)}

Khyber Pakhtunkhwa (KPK) is the third largest province with respect to population in Pakistan and is located in the northwest of the country. The total biodiesel potential from Khyber Pakhtunkhwa as per the estimates is 68,367 tonnes per year with 22 districts contributing to the number. The highest potential offered by a district in the province is 9616 tonnes per year from Peshawar followed by Dir and Mardan districts coming very close to each other but with a significant margin with Peshawar at 5366 tonnes per year and 5345 tonnes per year respectively. The detailed calculation and district-wise potential heat maps for Khyber Pakhtunkhwa are given in Table 3 and Fig. 4 respectively. 
Table 3 Biodiesel production potential from waste cooking oil in Khyber Pakhtunkhwa

\begin{tabular}{|c|c|c|c|c|c|}
\hline \multirow[t]{2}{*}{ District } & $\begin{array}{l}\text { Population in } \\
2017 \text { [56] }\end{array}$ & \multirow{2}{*}{$\begin{array}{l}\text { Per capita oil con- } \\
\text { sumption [15] } \\
\text { Tonnes/year }\end{array}$} & \multirow{2}{*}{$\begin{array}{l}\text { Oil consumption } \\
\text { Tonnes/year }\end{array}$} & \multirow{2}{*}{$\begin{array}{l}\text { Collectable oil }(20 \% \\
\text { Collection) } \\
\text { Tonnes/year }\end{array}$} & \multirow{2}{*}{$\begin{array}{l}\text { Biodiesel production [53] } \\
\text { Tonnes/year }\end{array}$} \\
\hline & Numbers & & & & \\
\hline Bannu & $1,167,892$ & \multirow[t]{24}{*}{0.017} & $19,854.2$ & 3970.8 & 2630.7 \\
\hline Lakki Marwat & 876,182 & & $14,895.1$ & 2979.0 & 1973.6 \\
\hline Dera Ismail Khan & $1,627,132$ & & $27,661.2$ & 5532.2 & 3665.1 \\
\hline Tank & 391,885 & & 6662.0 & 1332.4 & 882.7 \\
\hline Abbotabad & $1,332,912$ & & $22,659.5$ & 4531.9 & 3002.4 \\
\hline Battagram & 476,612 & & 8102.4 & 1620.5 & 1073.6 \\
\hline Haripur & $1,003,031$ & & $17,051.5$ & 3410.3 & 2259.3 \\
\hline Kohistan & 784,711 & & $13,340.1$ & 2668.0 & 1767.6 \\
\hline Mansehra & $1,556,460$ & & $26,459.8$ & 5292.0 & 3505.9 \\
\hline Hangu & 518,798 & & 8819.6 & 1763.9 & 1168.6 \\
\hline Karak & 706,299 & & $12,007.1$ & 2401.4 & 1590.9 \\
\hline Kohat & 993,874 & & $16,895.9$ & 3379.2 & 2238.7 \\
\hline Chitral & 447,362 & & 7605.2 & 1521.0 & 1007.7 \\
\hline Dir & $2,382,338$ & & $40,499.7$ & 8099.9 & 5366.2 \\
\hline Malakand & 720,295 & & $12,245.0$ & 2449.0 & 1622.5 \\
\hline Shangla & 757,810 & & $12,882.8$ & 2576.6 & 1707.0 \\
\hline Swat & $2,309,570$ & & $39,262.7$ & 7852.5 & 5202.3 \\
\hline Buner & 897,319 & & $15,254.4$ & 3050.9 & 2021.2 \\
\hline Mardan & $2,373,061$ & & $40,342.0$ & 8068.4 & 5345.3 \\
\hline Swabi & $1,624,616$ & & $27,618.5$ & 5523.7 & 3659.4 \\
\hline Charsadda & $1,616,198$ & & $27,475.4$ & 5495.1 & 3640.5 \\
\hline Nowshera & $1,518,540$ & & $25,815.2$ & 5163.0 & 3420.5 \\
\hline Peshawar & $4,269,079$ & & $72,574.3$ & $14,514.9$ & 9616.1 \\
\hline \multicolumn{4}{|c|}{ Total biodiesel production potential } & & $68,367.82594$ \\
\hline
\end{tabular}

Fig. 4 Biodiesel from waste cooking oil potential across Khyber Pakhtunkhwa

\begin{tabular}{|l|}
\hline Biodiesel Potential \\
KPK \\
Tonnes \\
$\square 883-1008$ \\
$\square 1009$ - 1169 \\
$\square 1170-1622$ \\
$\square 623-1768$ \\
$1769-2259$ \\
$2260-2631$ \\
$2632-3002$ \\
$3003-3665$ \\
$3666-5366$ \\
$5367-9616$ \\
\hline
\end{tabular}

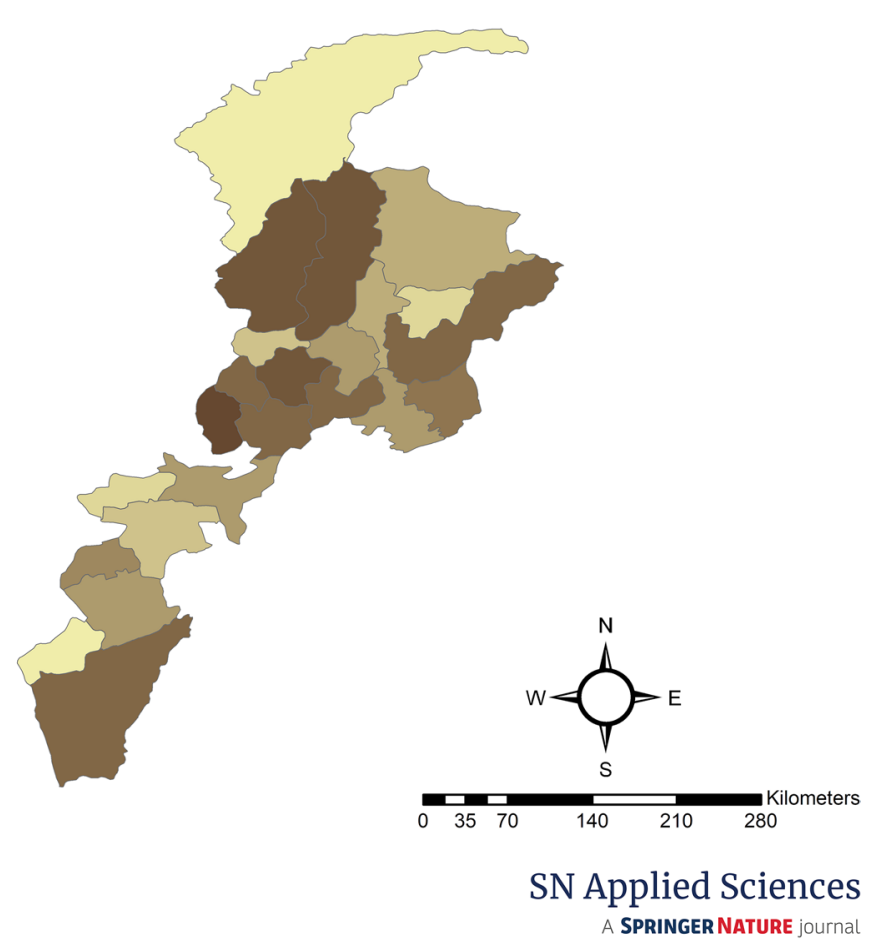


Fig. 5 Biodiesel from waste cooking oil potential across Balochistan

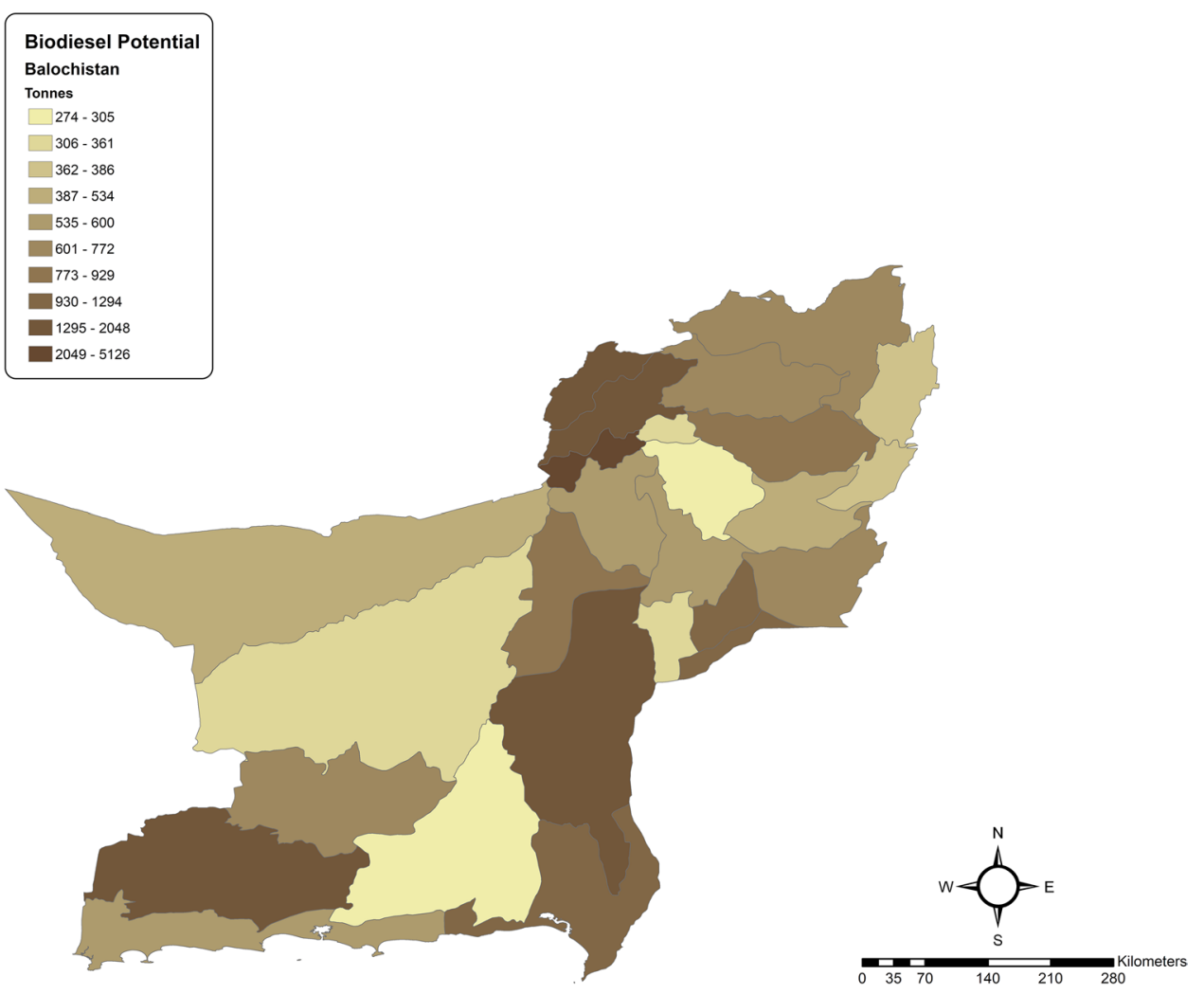

\subsection{Balochistan}

Balochistan is the fourth most highly populated province in the country. Balochistan is also the largest province with respect to area in the country but it is mostly uninhabitable due to severe climate. The heat map for the biodiesel production potential across the province is given in Fig. 5 where it can be seen that there are three major peaks for the province in terms of the higher potential for the biodiesel production from waste cooking oil which are irregularly spread across the province. The total potential that the province has to offer is 25,725 tonnes per year to which the highest contribution is from the provincial capital Quetta with it boasting a potential of 5126 tonnes per year of biodiesel production followed by Kech at 2047 tonnes per year of biodiesel potential and Khuzdar with 1807 tonnes per year. The detailed calculations and the district-wise potential is given in Table 4.

\subsection{Federally Administered Tribal Areas (FATA)}

The Federally Administered Tribal Areas is a territory on the western flank of the Khyber Pakhtunkhwa province and, as the name suggest is administered by the federal government of Pakistan. FATA boasts a large population, the highest in the non-province regions of Pakistan thus boasts the highest potential among the non-provincial territories. The total potential offered by FATA sits at 11,229 tonnes per year of biodiesel production from waste cooking oil with 10 districts contributing towards it. The heat map across the territory is given in Fig. 6 where it can be seen that the potential is peaking at two districts in the north. The highest potential comes from the northeastern district Bajaur at 2463 tonnes per year of biodiesel production followed by Khyber at 2223 tonnes per year of biodiesel production potential. The detailed calculation and the district-wise potential for biodiesel production from waste cooking oil from FATA is given in Table 5 .

\subsection{Azad Jammu and Kashmir (AJK)}

The recent population census of Pakistan didn't include the Azad Jammu and Kashmir and the data for it has been taken from the Government of AJK's statistical publication where they estimated the population since the last census via extrapolation [57]. The recorded total potential of the state is 8248 tonnes per year of biodiesel production from waste cooking oil with 8 districts contributing to this potential. Heat map for the state and the potential variation across the districts is 
Table 4 Biodiesel production potential from waste cooking oil in Balochistan

\begin{tabular}{|c|c|c|c|c|c|}
\hline \multirow[t]{2}{*}{ District } & $\begin{array}{l}\text { Population in } \\
2017 \text { [56] }\end{array}$ & \multirow{2}{*}{$\begin{array}{l}\text { Per capita oil con- } \\
\text { sumption [15] } \\
\text { Tonnes/year }\end{array}$} & \multirow{2}{*}{$\begin{array}{l}\text { Oil consumption } \\
\text { Tonnes/year }\end{array}$} & \multirow{2}{*}{$\begin{array}{l}\text { Collectable oil ( } 20 \% \\
\text { collection) } \\
\text { Tonnes/year }\end{array}$} & \multirow{2}{*}{$\begin{array}{l}\text { Biodiesel production [53] } \\
\text { Tonnes/year }\end{array}$} \\
\hline & Numbers & & & & \\
\hline Awaran & 121,680 & \multirow[t]{27}{*}{0.017} & 2068.6 & 413.7 & 274.1 \\
\hline Kalat & 412,232 & & 7007.9 & 1401.6 & 928.6 \\
\hline Kharan & 156,152 & & 2654.6 & 530.9 & 351.7 \\
\hline Khuzdar & 802,207 & & $13,637.5$ & 2727.5 & 1807.0 \\
\hline Lasbela & 574,292 & & 9763.0 & 1952.6 & 1293.6 \\
\hline Mastung & 266,461 & & 4529.8 & 906.0 & 600.2 \\
\hline Gwadar & 263,514 & & 4479.7 & 895.9 & 593.6 \\
\hline Kech & 909,116 & & $15,455.0$ & 3091.0 & 2047.8 \\
\hline Panjgur & 316,385 & & 5378.5 & 1075.7 & 712.7 \\
\hline Bolan & 237,030 & & 4029.5 & 805.9 & 533.9 \\
\hline Jafarabad & 513,813 & & 8734.8 & 1747.0 & 1157.4 \\
\hline Jhal Magsi & 149,225 & & 2536.8 & 507.4 & 336.1 \\
\hline Nasirabad & 490,538 & & 8339.1 & 1667.8 & 1104.9 \\
\hline Chaghi & 226,008 & & 3842.1 & 768.4 & 509.1 \\
\hline Pishin & 736,481 & & $12,520.2$ & 2504.0 & 1658.9 \\
\hline Qilla Abdullah & 757,578 & & $12,878.8$ & 2575.8 & 1706.4 \\
\hline Quetta & $2,275,699$ & & $38,686.9$ & 7737.4 & 5126.0 \\
\hline Dera Bugti & 312,603 & & 5314.3 & 1062.9 & 704.1 \\
\hline Kholu & 214,350 & & 3644.0 & 728.8 & 482.8 \\
\hline Sibi & 135,572 & & 2304.7 & 460.9 & 305.4 \\
\hline Ziarat & 160,422 & & 2727.2 & 545.4 & 361.4 \\
\hline Barkhan & 171,556 & & 2916.5 & 583.3 & 386.4 \\
\hline Loralai & 397,400 & & 6755.8 & 1351.2 & 895.1 \\
\hline Musakhel & 167,017 & & 2839.3 & 567.9 & 376.2 \\
\hline Qilla Saifullah & 342,814 & & 5827.8 & 1165.6 & 772.2 \\
\hline Zhob & 310,544 & & 5279.2 & 1055.8 & 699.5 \\
\hline \multicolumn{4}{|c|}{ Total biodiesel production potential } & & $25,725.10197$ \\
\hline
\end{tabular}

Fig. 6 Biodiesel from waste cooking oil potential across Federally Administered Tribal Areas

\begin{tabular}{|l|}
\hline Biodiesel Potential \\
FATA \\
Tonnes \\
$\square 156$ \\
$\square 157-267$ \\
$268-345$ \\
$268-573$ \\
$346-1052$ \\
$574-1053-1224$ \\
$1053-1396$ \\
$1225-1396$ \\
$1397-1530$ \\
$1531-2223$ \\
$2224-2464$ \\
\hline
\end{tabular}
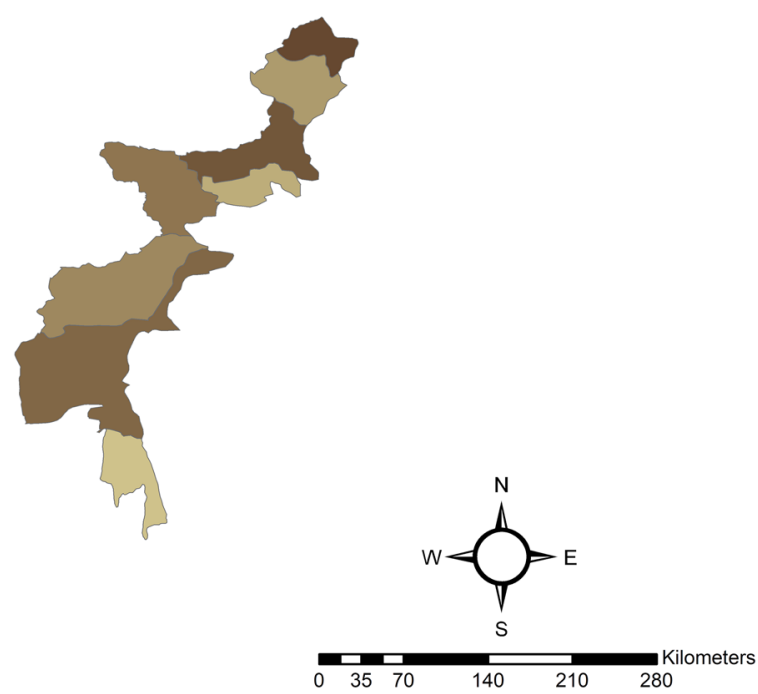

SN Applied Sciences

A SPRINGER NATURE journal 
Table 5 Biodiesel production potential from waste cooking oil in Federally Administered Tribal Areas

Fig. 7 Biodiesel from waste cooking oil potential across Azad Jammu and Kashmir

Table 6 Biodiesel production potential from waste cooking oil in Azad Jammu and Kashmir

\begin{tabular}{llllll}
\hline District & $\begin{array}{l}\text { Population } \\
\text { in 2017 [56] }\end{array}$ & $\begin{array}{l}\text { Per capita oil } \\
\text { consumption } \\
{[15]}\end{array}$ & Oil consumption & $\begin{array}{l}\text { Collectable oil } \\
\text { (20\% collection) }\end{array}$ & $\begin{array}{l}\text { Biodiesel } \\
\text { production } \\
\text { [53] }\end{array}$ \\
& Numbers & $\begin{array}{l}\text { Tonnes/year } \\
\text { Bajaur }\end{array}$ & Tonnes/year & Tonnes/year & Tonnes/year \\
Khyber & $1,093,684$ & 0.017 & $18,592.6$ & 3718.5 & 2463.5 \\
Kurram & 986,973 & & $16,778.5$ & 3355.7 & 2223.2 \\
Largha Shirani & 619,553 & & $10,532.4$ & 2106.5 & 1395.5 \\
Mohmand & 153,116 & & 2603.0 & 520.6 & 344.9 \\
North Waziristan & 546,984 & & 7938.7 & 1587.7 & 1051.9 \\
Orakzai & 254,356 & & 9235.3 & 1847.1 & 1223.7 \\
South Waziristan & 679,185 & 4324.1 & 864.8 & 572.9 \\
Adam Khel & 118,578 & $11,546.1$ & 2309.2 & 1529.9 \\
Bhittani & 69,473 & 2015.8 & 403.2 & 267.1 \\
Total biodiesel production potential & 1181.0 & 236.2 & 156.5 \\
\hline
\end{tabular}

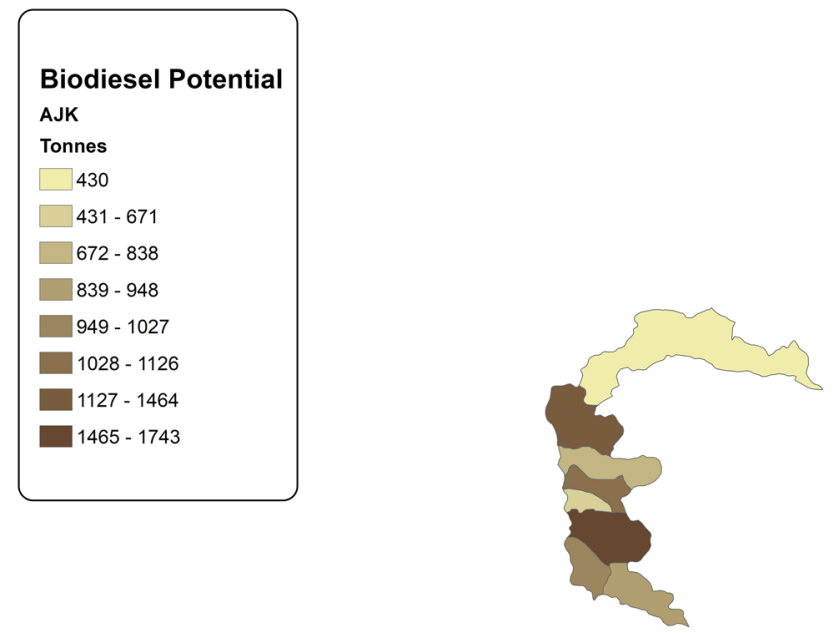

\begin{tabular}{|c|c|c|c|c|c|}
\hline \multirow[t]{2}{*}{ District } & $\begin{array}{l}\text { Population in } \\
2017 \text { [57] }\end{array}$ & $\begin{array}{l}\text { Per capita oil } \\
\text { consumption } \\
{[15]}\end{array}$ & Oil consumption & $\begin{array}{l}\text { Collectable oil } \\
\text { ( } 20 \% \text { collection) }\end{array}$ & $\begin{array}{l}\text { Biodiesel } \\
\text { production } \\
{[53]}\end{array}$ \\
\hline & Numbers & Tonnes/year & Tonnes/year & Tonnes/year & Tonnes/year \\
\hline Bagh & 372,000 & 0.017 & 6324.0 & 1264.8 & 837.9 \\
\hline Bhimber & 421,000 & & 7157.0 & 1431.4 & 948.3 \\
\hline Kotli & 774,000 & & $13,158.0$ & 2631.6 & 1743.4 \\
\hline Mirpur & 456,000 & & 7752.0 & 1550.4 & 1027.1 \\
\hline Muzaffarabad & 650,000 & & $11,050.0$ & 2210.0 & 1464.1 \\
\hline Neelum & 191,000 & & 3247.0 & 649.4 & 430.2 \\
\hline Poonch & 500,000 & & 8500.0 & 1700.0 & 1126.3 \\
\hline Sudhnati & 298,000 & & 5066.0 & 1013.2 & 671.2 \\
\hline \multicolumn{5}{|c|}{ Total biodiesel production potential } & 8248.655 \\
\hline
\end{tabular}


Fig. 8 Biodiesel from waste cooking oil potential across Gilgit-Baltistan
Table 7 Biodiesel production potential from waste cooking oil in Gilgit-Baltistan
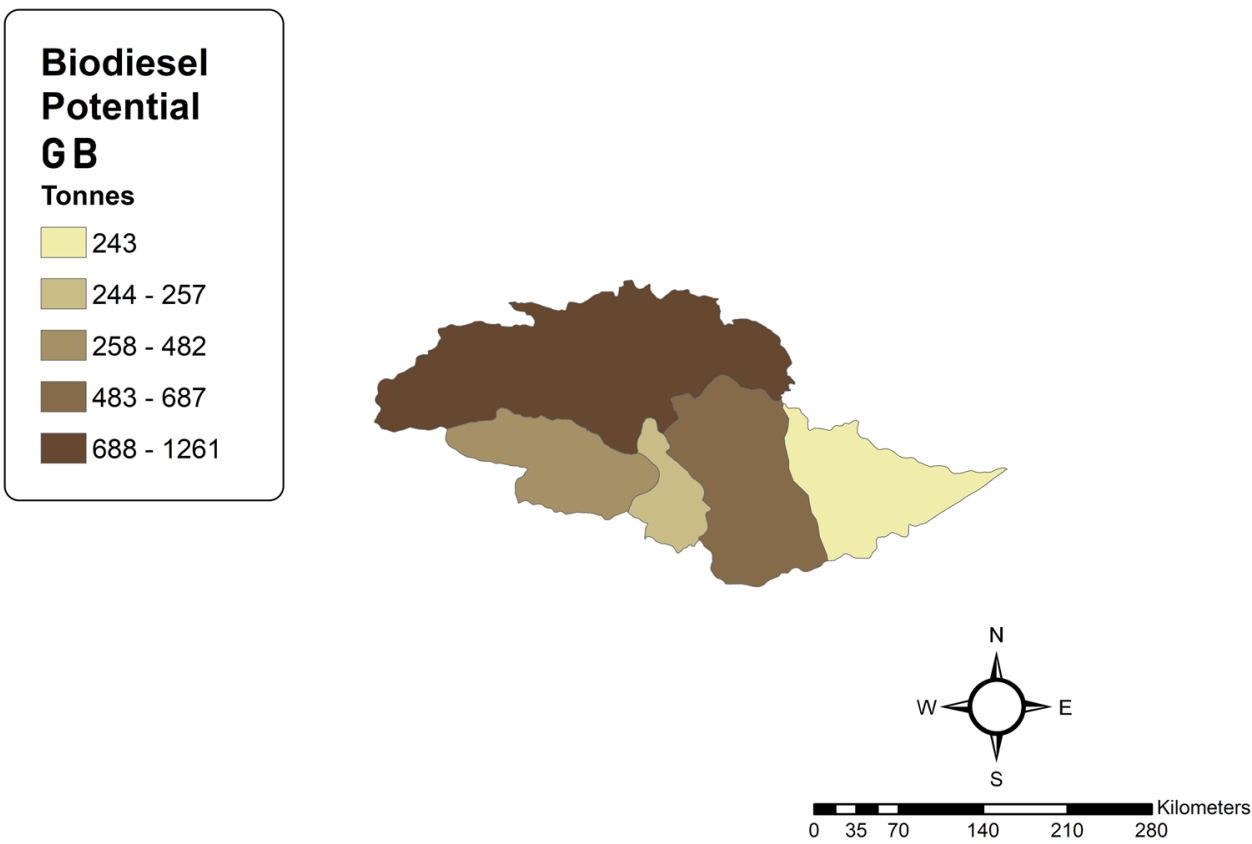

\begin{tabular}{llllll}
\hline District & $\begin{array}{l}\text { Population in } \\
2017[58]\end{array}$ & $\begin{array}{l}\text { Per capita oil con- } \\
\text { sumption [15] }\end{array}$ & Oil consumption & $\begin{array}{l}\text { Collectable oil } \\
\text { (20\% collection) }\end{array}$ & $\begin{array}{l}\text { Biodiesel } \\
\text { production } \\
\text { [53] }\end{array}$ \\
& Numbers & Tonnes/year & Tonnes/year & Tonnes/year & Tonnes/year \\
\hline Diamer & 214,000 & 0.017 & 3638.0 & 727.6 & 482.0 \\
Gilgit & 560,000 & & 9520.0 & 1904.0 & 1261.4 \\
Skardu & 305,000 & & 5185.0 & 1037.0 & 687.0 \\
Astore & 114,000 & & 1938.0 & 387.6 & 256.8 \\
Ghanche & 108,000 & 1836.0 & 367.2 & 243.3 \\
\multicolumn{7}{l}{ Total biodiesel production potential } & & & 2930.5025
\end{tabular}

given in Fig. 7. The highest potential for biodiesel production using waste cooking oil is offered by the Kotli district which offers a potential of 1743 tonnes per year of biodiesel production and is rather closely followed by Muzaffarabad at 1464 tonnes per year. The detailed calculation and district-wise potential for biodiesel production from waste cooking oil in Azad Jammu and Kashmir is given in the Table 6.

\subsection{Gilgit-Baltistan (GB)}

The population census of 2017 excluded Gilgit-Baltistan with the Azad Jammu and Kashmir as well and therefore the extrapolated data from the Gilgit-Baltistan government has been used which was only available till the year 2013 [58]. The total potential boasted by the region is 2,930 tonnes of annual biodiesel production per year. The heat map for the variation within the districts has been given in Fig. 8. It can be seen that the Gilgit district has the highest potential to offer at 1261 tonnes per year of biodiesel production followed by Skardu at 687 tonnes per year of biodiesel potential. The detailed calculation and the tabular expressions for the district-wise variation across Gilgit-Baltistan is given in Table 7.

\subsection{Discussion}

Taking a look at the work done on the waste cooking oil to biodiesel technology, we come across a lot of work on the type of catalyst that should be used for transesterification $[59,60]$. Another area that the scientific community has contributed to the knowledge about the technology is the assessment of the fuel on whether it is suitable to be used in existing energy systems $[35,43,61]$. Such studies have established the foundation for the researchers to build on to experiment on the real life adaptability of the technology. The studies like techno-economic analyses, identification of social barriers in the adoption and the resource 
assessments are needed for the technology. This study assesses the resource's potential using statistical methods to represent using GIS maps. This approach has been reported for the resource assessment of bioenergy by various authors $[24,33]$. The approach used by the other similar studies to assess the resource potential is often driven by the remote sensing, especially when the study deals with crop residues. That approach renders fairly accurate results but demands for the resource in consideration be remote sensing capable such as land cover. The resources like waste cooking oil or municipal solid waste that usually rely on per capita waste production and the population density cannot benefit from the remote sensing [1]. This study uses the statistical estimation for the resource potential and maps it on the GIS based maps which is a logically sound approach to take for such resources and has been reported [32]. The study projects the availability of a sustainable resource for biodiesel production alongside the heat-maps for the potential of the resource. In order for the scientific community to bring the biodiesel production technology to the mainstream, the studies like this, using sustainable resources that do not pose any challenges to land use and food security, are needed. This study has the potential to motivate young researchers to delve into the resource assessment of waste cooking oil to biodiesel technology as well as to act as a guide for them in doing so.

\section{Conclusion}

Though there have been some efforts made by the local scientific community in putting forth the use of waste cooking oil for biodiesel production with some very genuine approaches towards establishing the resource in the country $[12,62,63]$, none pertained to the spatial availability assessment as carried out in this study. The total potential of biodiesel production from waste cooking oil assuming collection of just the $20 \%$ of waste cooking oil and a mere $66.25 \%$ oil conversion ratio is 468,842 tonnes per year of biodiesel with the highest share for it coming from Punjab at 249,260 tonnes per year of biodiesel from cooking oil. In case the results from the authors who reported the diesel extraction from the waste cooking oil to be $90 \%$ [38-40] were to be taken into account, the total potential offered by the country with the same $20 \%$ of residual cooking oil recover would soar up to 636,918 tonnes per year of biodiesel from waste cooking oil with the contribution from Punjab soaring up to 338,617 tonnes per year of biodiesel. Some of the recommendations in order to bring about this resource being utilized for biodiesel production are as follows:
- Subsidizing the investments in the bio-energy sector by using similar strategies used to establish the solar energy technology markets in the country.

- Introduction of Carbon tax on the high emitter industries and sectors to promote the use of clean and green fuels.

- Introduction of waivers to the introduced Carbon taxes for the high emitters investing in the sector by building biodiesel production units from waste cooking oil and other resources.

- Introduction of the tradable waste disposal charges to the restaurants and the domestic consumers based on the scale of waste generation offering trade with the waste cooking oil provision in form of waivers to the disposal costs.

- Urging the major oil refineries in the country to set up a unit for waste cooking oil to biodiesel production in their respective cities of operation.

- Diversion of the transport sector from import based diesel to the biodiesel by government anchored biodiesel production plants for the public transport in the respective cities of production.

- Encouraging entrepreneurship in the bio-energy sectors by initiating easy loans for the startups around bioenergy and biodiesel production from waste cooking oil.

This study is an evidence of the realistic potential that the waste cooking oil to biodiesel production poses in the country which can not only help the country reach its target of having $10 \%$ share of biofuels in the country's petroleum sector but also reduce the burden on the country's economy in the form of both edible and crude oil imports by effectively utilizing the former to reduce the import of the latter.

\section{Compliance with ethical standards}

Conflict of interest The authors hereby declare that they have no conflict of interests. It is to further affirm that there are no conflicting interests with any of the authors and co-authors to declare andwe, thus, hereby declare no conflicting interests. The study is being submitted to the SN Applied Sciences Journal andit is to declare that none of the contents of the study or the manuscript itself have been put forth for the publication inany other journal or any such platform at the time of submission and will remain so till the final decision about thesubmission is made.

\section{References}

1. Korai MS, Mahar RB, Uqaili MA (2017) The feasibility of municipal solid waste for energy generation and its existing 
management practices in Pakistan. Renew Sustain Energy Rev 72:338-353

2. Fahad S, Wang J (2018) Farmers' risk perception, vulnerability, and adaptation to climate change in rural Pakistan. Land Use Policy 79:301-309

3. Hussain M et al (2018) Regional and sectoral assessment on climate-change in Pakistan: social norms and indigenous perceptions on climate-change adaptation and mitigation in relation to global context. J Clean Prod 200:791-808

4. Pakistan Bureau of Statistics (2018) Economic survey of Pakistan 2017-18 Chapter 14 - energy

5. OGRA (2016) State of the regulated petroleum industry 201617 , vol 1

6. Alternate Energy Development Board (2018) Current status of bioenergy in Pakistan - AEDB. https://www.aedb.org/ae-techn ologies/biomass-waste-to-energy/current-status. Accessed 21 Dec 2018

7. Government of Pakistan (2006) Policy for development of renewable energy for power generation

8. Rauf O, Wang S, Yuan P, Tan J (2015) An overview of energy status and development in Pakistan. Renew Sustain Energy Rev 48:892-931

9. Sher HA, Murtaza AF, Addoweesh KE, Chiaberge M (2015) Pakistan's progress in solar PV based energy generation. Renew Sustain Energy Rev 47:213-217

10. The World Bank (2016) Biomass resource mapping in Pakistan: final report on biomass atlas, pp 1-91

11. Shah SH et al (2018) Potential of microalgal biodiesel production and its sustainability perspectives in Pakistan. Renew Sustain Energy Rev 81:76-92

12. Khan HM et al (2018) Current scenario and potential of biodiesel production from waste cooking oil in Pakistan: an overview. Chin J Chem Eng 27:2238-2250

13. Ali M, Sultana R, Tahir S, Watson IA, Saleem M (2017) Prospects of microalgal biodiesel production in Pakistan-a review. Renew Sustain Energy Rev 80:1588-1596

14. Siddiqi A, Wescoat JL, Muhammad A (2018) Socio-hydrological assessment of water security in canal irrigation systems: a conjoint quantitative analysis of equity and reliability. Water Secur 4-5:44-55

15. G. Ministry of Finance (2018) Pakistan economic survey 2017-18

16. Fazal T et al (2018) Bioremediation of textile wastewater and successive biodiesel production using microalgae. Renew Sustain Energy Rev 82:3107-3126

17. Rashid N, Rehman MS, Sadiq M, Mahmood T, Han J-I (2014) Current status, issues and developments in microalgae derived biodiesel production. Renew Sustain Energy Rev 40:760-778

18. Gondal IA, Masood SA, Amjad M (2017) Review of geothermal energy development efforts in Pakistan and way forward. Renew Sustain Energy Rev 71:687-696

19. Pakistan State Oil, "Biodiesel | Pakistan State Oil". https:// psopk.com/en/product-and-services/alternate-fuels/biodi esel. Accessed 20 Jan 2019

20. International Energy Agency (2016) IEA - Pakistan. https:// www.iea.org/policiesandmeasures/pams/pakistan/name38078-en.php?s=dHIwZT1yZSZzdGF0dXM9T2s,\&retur n=PG5hdiBpZD0iYnJIYWRjcnVtYil-PGEgaHJIZjOiLyl-SG9tZ TwvYT4gJnJhcXVvOyA8YSBocmVmPSIvcG9saWNpZXNhbm RtZWFzdXJIcy8iPIBvbGljaWVzIGFuZCBNZWFzdXJIczwvYT4g JnJhc. Accessed 20 Jan 2019

21. O'Keeffe S, Majer S, Drache C, Franko U, Thrän D (2017) Modelling biodiesel production within a regional context-a comparison with RED Benchmark. Renew Energy 108:355-370
22. Fawaz EG, Salam DA (2018) Preliminary economic assessment of the use of waste frying oils for biodiesel production in Beirut, Lebanon. Sci Total Environ 637-638:1230-1240

23. Morato T, Vaezi M, Kumar A (2019) Assessment of energy production potential from agricultural residues in Bolivia. Renew Sustain Energy Rev 102:14-23

24. Thomas A, Bond A, Hiscock K (2013) A GIS based assessment of bioenergy potential in England within existing energy systems. Biomass Bioenergy 55:107-121

25. Zyadin A et al (2018) Estimation of surplus biomass potential in southern and central Poland using GIS applications. Renew Sustain Energy Rev 89:204-215

26. Yousefi H, Noorollahi Y, Hajinezhad A, Alimohammadi A (2017) GIS-based spatially integrated bioenergy resources assessment in Kurdistan Province-Northwest Iran. Sustain Energy Technol Assess 23:11-20

27. Sidiras DK (2014) GIS based simulation of the biodiesel penetration in European Union markets: the case of Greece. Biomass Bioenergy 65:101-111

28. Brusca S, Famoso F, Lanzafame R, Messina M, Monforte $P$ (2017) Placement optimization of biodiesel production plant by means of centroid mathematical method. Energy Proc 126:353-360

29. Keson J, Ratchaniphont A, Wongsai S, Wongsai N (2015) Policy Assessment of potential biodiesel feedstock supply in Thailand. Energy Proc 79:710-718

30. Mohseni S, Pishvaee MS, Sahebi H (2016) Robust design and planning of microalgae biomass-to-biodiesel supply chain: a case study in Iran. Energy 111:736-755

31. Long H, Li X, Wang H, Jia J (2013) Biomass resources and their bioenergy potential estimation: a review. Renew Sustain Energy Rev 26:344-352

32. Hiloidhari $\mathrm{M}$ et al (2017) Emerging role of geographical information system (GIS), life cycle assessment (LCA) and spatial LCA (GIS-LCA) in sustainable bioenergy planning. Bioresour Technol 242:218-226

33. Hiloidhari M, Das D, Baruah DC (2014) Bioenergy potential from crop residue biomass in India. Renew Sustain Energy Rev 32:504-512

34. Rehman MSU, Rashid N, Saif A, Mahmood T, Han J-I (2013) Potential of bioenergy production from industrial hemp (Cannabis sativa): Pakistan perspective. Renew Sustain Energy Rev 18:154-164

35. Madheshiya AK, Vedrtnam A (2018) Energy-exergy analysis of biodiesel fuels produced from waste cooking oil and mustard oil. Fuel 214:386-408

36. Dhawane SH, Karmakar B, Ghosh S, Halder G (2018) Parametric optimisation of biodiesel synthesis from waste cooking oil via Taguchi approach. J Environ Chem Eng 6(4):3971-3980

37. Ahmad Farid MA, Hassan MA, Taufiq-Yap YH, Shirai Y, Hasan MY, Zakaria MR (2017) Waterless purification using oil palm biomassderived bioadsorbent improved the quality of biodiesel from waste cooking oil. J Clean Prod 165:262-272

38. Sahar et al (2018) Biodiesel production from waste cooking oil: An efficient technique to convert waste into biodiesel. Sustain Cities Soc 41:220-226

39. Mansir N, Teo SH, Rabiu I, Taufiq-Yap YH (2018) Effective biodiesel synthesis from waste cooking oil and biomass residue solid green catalyst. Chem Eng J 347:137-144

40. Jung J-M, Oh J-I, Baek K, Lee J, Kwon EE (2018) Biodiesel production from waste cooking oil using biochar derived from chicken manure as a porous media and catalyst. Energy Convers Manag 165:628-633

41. Leung DYC, Wu X, Leung MKH (2010) A review on biodiesel production using catalyzed transesterification. Appl Energy 87(4):1083-1095 
42. Mohadesi M, Aghel B, Maleki M, Ansari A (2019) Production of biodiesel from waste cooking oil using a homogeneous catalyst: study of semi-industrial pilot of microreactor. Renew Energy 136:677-682

43. Abed KA, El Morsi AK, Sayed MM, El Shaib AA, Gad MS (2018) Effect of waste cooking-oil biodiesel on performance and exhaust emissions of a diesel engine. Egypt J Pet 27(4):985-989

44. Gao Y, Chen Y, Gu J, Xin Z, Sun S (2019) Butyl-biodiesel production from waste cooking oil: kinetics, fuel properties and emission performance. Fuel 236:1489-1495

45. García-Martín JF, Barrios CC, Alés-Álvarez F-J, Dominguez-Sáez A, Alvarez-Mateos P (2018) Biodiesel production from waste cooking oil in an oscillatory flow reactor. Performance as a fuel on a TDI diesel engine. Renew Energy 125:546-556

46. Yesilyurt MK (2019) The effects of the fuel injection pressure on the performance and emission characteristics of a diesel engine fuelled with waste cooking oil biodiesel-diesel blends. Renew Energy 132:649-666

47. Almenhali A, Hamad I, Alshehhi M, Alsuwaidi N, Mohamed S (2011) Enzymatic production of biodiesel from used/ waste vegetable oils: design of a pilot plant. Renew Energy 36(10):2605-2614

48. Samad ATP, Perdani MS, Putri DN, Hermansyah H (2018) Technoeconomic analysis of portable plant from waste cooking oil. Energy Proc 153:269-273

49. Lisboa P, Rodrigues AR, Martín JL, Simões $P$, Barreiros S, Paiva A (2014) Economic analysis of a plant for biodiesel production from waste cooking oil via enzymatic transesterification using supercritical carbon dioxide. J Supercrit Fluids 85:31-40

50. Asif S, Ahmad M, Zafar M, Ali N (2017) Prospects and potential of fatty acid methyl esters of some non-edible seed oils for use as biodiesel in Pakistan. Renew Sustain Energy Rev 74:687-702

51. Liu T et al (2018) Restaurants' behaviour, awareness, and willingness to submit waste cooking oil for biofuel production in Beijing. J Clean Prod 204:636-642

52. Avinash A, Sasikumar P, Murugesan A (2018) Understanding the interaction among the barriers of biodiesel production from waste cooking oil in India-an interpretive structural modeling approach. Renew Energy 127:678-684
53. Cordero-Ravelo V, Schallenberg-Rodriguez J (2018) Biodiesel production as a solution to waste cooking oil (WCO) disposal. Will any type of WCO do for a transesterification process? A quality assessment. J Environ Manag 228:117-129

54. Haase M, Rösch C, Ketzer D (2016) GIS-based assessment of sustainable crop residue potentials in European regions. Biomass Bioenergy 86:156-171

55. Bureau of Statistics Punjab (2017) Punjab Development Statistics 2017

56. Pakistan Bureau of Statistics (2017) Pakistan Bureau of Statistics | 6th Population and Housing Census. https://www.pbscensus. gov.pk/. Accessed 10 Jan 2019

57. P. and D. D. of AJK (2017) AJ\&K statistical yearbook 2017. https ://www.pndajk.gov.pk/statyearbook.php. Accessed 10 Jan 2019

58. Government of Gilgit-Baltistan (2013) Gilgit Baltistan at a Glance - 2013, Gilgit

59. Kataria J, Mohapatra SK, Kundu K (2019) Biodiesel production from waste cooking oil using heterogeneous catalysts and its operational characteristics on variable compression ratio $\mathrm{Cl}$ engine. J Energy Inst 92(2):275-287

60. Borah MJ, Das A, Das V, Bhuyan N, Deka D (2019) Transesterification of waste cooking oil for biodiesel production catalyzed by $\mathrm{Zn}$ substituted waste egg shell derived $\mathrm{CaO}$ nanocatalyst. Fuel 242:345-354

61. Shen X et al (2018) Real-world exhaust emissions and fuel consumption for diesel vehicles fueled by waste cooking oil biodiesel blends. Atmos Environ 191:249-257

62. Khan NA, el Dessouky H (2009) Prospect of biodiesel in Pakistan. Renew Sustain Energy Rev 13(6-7):1576-1583

63. Chakrabarti MH et al (2012) Status of biodiesel research and development in Pakistan. Renew Sustain Energy Rev 16(7):4396-4405

Publisher's Note Springer Nature remains neutral with regard to jurisdictional claims in published maps and institutional affiliations. 